\title{
Influence of Personality Types and Socio-Demographic Characteristics of Work-Study Students at a Private University, Southwest Nigeria
}

\author{
Tayo, 0. George \\ Department of Sociology, Covenant University, P. M. B. 1023, Ota, Southwest Nigeria \\ Michael Chibuzor, Anyaegbunam \\ Department of Psychology, Nnamdi Azikiwe University, P.M.B 5025, Awka, Anambra State, Southeast Nigeria \\ Dominic, Azuh \\ Department of Economics and Development Studies, Covenant University, P. M. B. 1023, Ota, Southwest Nigeria \\ Bernard Chukwukelue, Chine \\ Department of Psychology, Nnamdi Azikiwe University P.M.B 5025, Awka, Anambra State, Southeast Nigeria

\section{Dare Ojo, Omonijo (Corresponding Author)} \\ Department of Sociology, Covenant University, P. M. B. 1023, Ota, Southwest Nigeria \\ Email: oluwadare.omonijo@covenantuniversity.edu.ng
}

\author{
Doi:10.5901/mjss.2015.v6n6s4p452
}

\section{Abstract}

This study examined the influence of personality types and socio-demographic characteristics on work-study of students at Covenant University, Ota. The study used questionnaires to collect information from 100 students who participated in the programme in 2014/2015 academic session. The chi- $x^{2}$ result of 12.30 for the variable responses showed that the age and the sex of students influenced their participation in work study programme with chi- $x^{2}$ (29.80), degree of freedom 4 and significance level of $1 \%$ of the combined result respectively. The finding of investigation also show that birth order influenced students participation in work study initiative with chi- $x^{2}$ distribution of 19.70 , degree of freedom of 4 and asymptotic significance of $1 \%$. Also, the result of the T-statistics (28.23) with the degree of freedom 99 revealed significance among the Personality Type "A" and " $B$ " compositions at $1 \%$ level of significance. The estimated correlation coefficient indicates a significant strong correlation (0.630) between the response variables "Personality Type" and influence on student participation in work study programme.

Keywords: Influence, personality types, socio-demographic characteristics, work-study student.

\section{Introduction}

In view of the advanced level of education system in developed nations, a series of initiatives have evolved to ensure students' development. One of such initiatives is work-study scheme. The scheme is generally regarded as a temporary job opportunity provided to indigent students in tertiary institutions to enable them complete their programmes of study. However, it should be noted that the assignments involved are not comparable with those of full-time appointments usually given to employees in normal work organisations. The study of (Ndagana and Ogunronbi, 2006; Adewale and Ajayi, 2010; Omonijo, Oludayo, Uche and Rotimi 2014; Oludayo, Omonijo, Uche and Nwadiolor, 2014) specifically highlights jobs in this scheme since its inception in tertiary institutions in Nigeria.

The importance of this scheme on students' empowerment has been fully expressed in the literature in developed nations higher education system (National Center for Education Statistics 1994; Mark, Ernest, Ryan and Charles 2012). Some of these studies show that the scheme, to a greater extent, has increased the access of namy indigent youth to higher education (Cuccaro-Alamin and Choy, 1998). In other words, indigent students who could not access higher education were able to do so through the initiative. Other important vital contributions of work-study initiative to student 
development have been discussed (Ehrenberg and Sherman, 1986). The work of Furr and Elling (2000), for instance, focuses on the positive impact of this scheme on students' work related experience after their graduation. The expediency of this may not be easily ignored, when students begin to apply for work in work settings after their studentship. To some extent, it could allow students who participate in the programme to be rated better than their counterparts during interview. In another dimension, scholars such as (Henry 1967; Stern and Nakata, 1991) discuss the negative implications of work study scheme on students' academic performance on campus. In this regard, students who do not have the capacity to combine work with their studies, and usually they are the average ones, may likely find it difficult to cope with the initiative.

However, since inception of students' empowerment initiative in sub-Sahara African (SSA) higher education system, articles on work-study experience have not been fully explored in the literature. Although a study was conducted on work-study in Zambia by Kanyengo (2008) while scholars such as (Ndagana and Ogunronbi 2006; Adewale and Ajayi, 2010; Oludayo, et al., 2014; Omonijo, et al., 2014; Omonijo, Anyaegbunam, Oludayo and Nnedum, 2015) have investigated some vital social life issues on student work-study scheme in Nigerian higher education system and made significant contributions to the body of knowledge. Nevertheless, the influence of personality types and sociodemographic characteristics of students on work-study programme have hitherto been neglected in the literature. Thus, there is a dearth of literature on the influence of personality types and the socio-demographic characteristics of students on work study initiative. The present study was conceived to fill this gap in knowledge from the perspective of a private sector university in Nigeria.

This effort, apart from its academic value to the body of knowledge, could be more relevant considering the usefulness of personality traits. Yousef and El-Houfey, (2014) in predicting a variety of different important life outcomes academically, physically, psychologically, occupationally, socially, as well as health and community involvement among many others (Ozer and Benet-Martinez 2006). Therefore, objectives of this study are to investigate if: (i) sociodemographic characteristics-age, gender and birth order influence the participation of students in work study programme, (ii) there is correlation between Personality Type ' $A$ ' and ' $B$ ' on students participation in work study initiative.

This study is organized in the following four parts: Literature review, methodology, findings, conclusion and recommendations.

\subsection{Operational Definition of Terms}

Personality - This is generally regarded as a group of traits that can be used to categorize people

Work-Study - Programme / scheme / initiative designed for indigent students to enable them to complete their programme of study while in school.

Influence - Effects of something on another thing(s).

\section{Literature Review}

\subsection{Examination of Research on Personality}

Eysenck and Eysenck (1975) view Personality Types in the following four ways: extroversion-introversion, neuroticismstability, psychoticism and lie. However, this study is limited to two Personality Types as discussed below:

\subsection{Personality Type A}

People are classified into Personality Type 'A' or Personality Type 'B' (Glass 1977) based on certain characteristics. Personality Type 'A' persons are said to be hardworking, ambitious, highly competitive, achievement-oriented and striving. Such persons believe that with enough effort, they can overcome any obstacle easily (Rotimi, Omonijo and Uche, 2014). The work of Scott (2015) corroborates the submission of Rotimi et al., (2014) who claims that Personality Type 'A' individuals are often highly achieving and workaholics of multi-task. Scott, (2015) argue further that Personality Type 'A' persons drive themselves with deadlines, and are unhappy about the smallest of delay encountered in the course of getting tasks done..

With due regard to this study however, Personality Type 'A' students may be influenced to indulge in the workstudy initiative by the above stated straits. Since they are very hardworking and have the capacity to engage in multiple tasks, combining the scheme with academic activities might not be a problem to them. Only students who cannot combine their studies with work can be greatly affected as argues by (Nekhwevha, 1999). According to this author, nearly 
$50 \%$ of all full-time students are working enough hours to hinder their academic experience, including grade performance, class schedule, and class choice.

Also, considering the attributes of Personality Type ' $A$ ' which hinges on ambition, highly competitiveness, achievement-oriented and striving, students in this personality type could see the work study scheme as a way of securing work-related experiences, so as to be placed above their colleagues, when attending interview in work settings after graduation. Considering the rate of unemployment in the Nigerian labour market today, which stands at $23.90 \%$, (National Bureau of Statistics, 2015 cited in Omonijo et al., 2015), such students might want to be planning ahead on how to beat their counterparts in course of interview for work placement after graduation.

\subsection{Personality Type $B$}

Previous studies show that personality Type 'B' persons possess some of the features of Personality Type 'A' (Aliyu and Adeoye, 1991). These traits include a general expression of relaxation, calm and quite attention, never cares to compete excessively or form a race with time, an absence of emphatic one word response, rarely sighs when he/she is showing nervous anxiety, no evidence of clipped speech and slow to moderate pacing of verbal responses (Aliyu and Adeoye, 1991). However, Rotimi et al., (2014) argue otherwise by indicating that Personality Type 'B' individuals have some behaviour patterns that are converse or the reverse of Type 'A' Behavioural Patterns (TABP). The work of Rosenman and Friedman (1974) corroborates the submission of Rotimi et al., (2014) on this discourse. According to these authors, Personality Type ' $\mathrm{B}$ ' persons are rarely hurried by desires to obtain a widely increasing number of things or participate in jobs that demand an ever-decreasing amount of time. Thus, Personality Type 'B' people are relaxed, less stressed, flexible, emotional and expressive, and have a laid-back attitude (Lombardo, 2015). Similarly, Diego (2015) identifies the following characteristics of the Type 'B' personality: stress handling, lack of urgency, procrastination, relaxed, nonaggressive, socializing and enjoying.

Given the above stated attributes, Personality Type 'B' students may not want to be involved in work-study scheme. This could be attributed to the following two reasons:

Firstly, Personality Type 'B' students may find it very difficult to combine academic activities with the work schedule. This is because most of them do not possess the capacity for multi-tasks. .Anybody who is too relaxed and delay in getting assignments done may not be able to combine multiple assignments together and perform very well.

Secondly, since Personality Type 'B' persons are not highly competitive. They are people who remain calm and relaxed most of the times. Also, they do not possess anxiety over failing to perform tasks on time. Students who are Personality Type 'B' may not be bothered to engage in work study scheme for work related experience after graduation. So, the idea of being placed above their mates during interview may not arise. Although it has been argued that Personality Type ' $B$ ' persons can be achievers too but they may not be as competitive as Personality Type 'A' individuals. This is because they may delay work and do it in the last moment. Also, Personality Type 'B' can be actively involved in procrastination but that is not peculiar with Personality Type 'A' persons.

\subsection{Socio-Demographic Characteristic of Students}

Given the submission of Mazarian of (2012), demography is the scientific study of characteristics and dynamics pertaining to human population. This author advances that it involves education, income, the structure of the family unit, housing, race or ethnicity, and religion. However, the characteristics formation of this study include, age, sex and birth order of students who engaged in work study programme. Socio-economic characteristics of students in different areas of life have attracted studies in the past and in recent times. For instance, Jalilian, Karami, Ahmadpanah, Ataee, Ahmadi, Eslami, Mirzaei, (2015) focus on the Socio-demographic characteristics of students in connection with cigarettes smoking, drug abuse and alcohol drinking among male medical university in Iran while a study conducted by Marino, (2015), deals with the socio-demographic characteristics of dental students in Australia, Chile, and New Zealand. The study of Oswald, Coutinho, Best, Nguyen (2001) as well highlights the impact of socio-demographic characteristics on the identification rates of minority Students as having mental retardation.

Dwelling on the above, the importance of socio-demographic characteristics of students on several issues of life cannot be over emphasized. It has been used to explain social life issues of concerned among students in many developed nations. However, such efforts have not been intensified in academia, mostly on work study students in SSA. Therefore, this study intends to address this gap in knowledge using a private university, southwest Nigeria as a focus. The key Socio-Demographic characteristics pertaining to this study are succinctly discussed below: 


\subsubsection{Age}

It is evident in literature that age is very crucial to job placement in work orgainsations (Rhodes, 1983; Warr, 1994). In many work-settings, young staff are often recruited for training and development (Maurer and Rafuse, 2001). When they are employed, they are sent on courses, programmes and inductions aimed at development. Such members of staff are not given jobs which require long years of experiences and they are regarded to as graduate trainees. According to Hill (2001), older staff are not considered when it comes to this type of employments.

Age in work placement is very important because it determines, in most cases, workers maturity and ability to handle sensitive assignments. There is every tendency for employees to give preference to older staff when it comes to assignments that require cognate experiences. Young workers may likely mess up such assignments due to their immaturity. It takes many years of engagement and training to build up experience, confidentiality and mastery for performance in certain employments. It only makes sense to employ such persons because they have acquired more knowledge that is relevant to the task at hand.

In respect of work study programme, age may be regarded as a crucial criterion for recruitment because; the scheme provides an opportunity for training young students for future employment. In another development, it may not be regarded as a crucial criterion because assignments that are usually assigned to such students are not complex ones. They are minor assignments that required students knowing the rudimentary of work place and to be familiar with it. However, students who are not used to daily shores at home may either find it difficult to cope with work study initiative. Such students may not be interested in the programme, while others may be interested in knowing how to work and wants to use the opportunity offered by the work study as a starting point.

\subsubsection{Sex}

Gender factor is of paramount importance to cognitive, affective and behavioral actions of individuals Rotimi et al., (2014). Following the same line of argument, Igborgbor and Igbrobor, (1999) submit that there are biological based differences in brain component, which account for men's higher spatial, numerical and independent cognitive styles. In other words, men and women behave differently because of variation in their psychological constitution along gender lines without much consideration to environmental influence. Such claims according to Ossai, (2004) cited in Rotimi et al., (2014) have given rise to investigations of gender difference in psychology, counseling and educational issues.

Growing up as a male or female child may likely have influence on Personality types. It implies having 'masculine' or 'feminine' traits or be a male or female could influence participation of students in work and study initiative? A student who is masculine tends to be aggressive, analytical, assertive, athletic, competitive, decisive, dominant, forceful, independent, individualistic, self-reliant, and willing to take risk Rotimi et al., (2014) while a student who is feminine tends to be affectionate, cheerful, loyal, sensitive, shy, self-spoken, sympathetic, tender understanding, warm and yielding (Rotimi et al., 2014). Therefore, feminine students could be considered more than their masculine counterparts in Hall of residence assignments, library and computer duties that demand special treatments for students.

\subsubsection{Birth Order}

Birth order simply means the chronological order of sibling births in a family (Franz, 2006). The impact of birth order on personality has attracted scholarly work in the past and in recent times. However, Franz (2006) traces the origin of academic work on this subject to Alfred Adler (1870-1937). According to this author, Alfred Adler was one of the first theorists to suggest that birth order influences personality of mankind. He argued that birth order; more often than not leave an indelible impression on the individual's life style. This is a habitual way of people dealing with the tasks of friendship, love, and work. Also, Bayer (1967) views that social researchers have been giving increasing attention over the past century to the effect of sibling position on personality formation and on their behaviours and attitudes. This author believes that one of the most striking birth-order effects, and also one of the most researched relationships using personality formation is the association between one's sibling position and his or her capability to achieve greatness in life. However, research in the late $20^{\text {th }}$ and early $21^{\text {st }}$ centuries in developed nations show greater influence of birth order and its contribution to intelligence, career choice, and, to a certain degree, success in adulthood (Toman, 1993; Leman, 1998; Wallace, 1999).

Few of such studies have emerged in higher education system in Nigeria. One of such is Rotimi, Omonijo and Uche, (2014). These authors argue that birth order in a family setting has a significant impact on personality. They also believe that first born children seem to have a higher chance of attaining greatness than latter-born persons. Later studies 
in other countries have shown that more first born children usually become National Merit Scholars. The study of Humphreys and Revelle, (1984) also shows that many of them are successful medical or graduate students

More specific research on the effects of birth order has generally focused on five ordinal birth positions. These include first-born, second-born, middle, last, and only-born child in a family. Viewpoints of scholars on each of the above mentioned orders of birth are hereby presented below.

\subsubsection{First-born}

First born children are the first children in families. More attention of parents if usually focused on them because it is generally believed that they will be able to monitor other siblings. In some culture such as the Yorubas in the Southwest geo-political zone of Nigeria, it is generally believed that first born children are good examples to other children in the family. Although some of them behave otherwise, but most people are of the view that they influence other siblings positively. This is manifested in the popular dictum of people in the area 'esin iwaju niti ehin nwo sa ere' meaning, the speed of the horse in front determines the speed of horses at the back. In the light of the above, Franz (2006) believes that first born children are generally responsible, assertive, and task-oriented, often rising to leadership positions as adults. They are more frequently mentioned in Who's Who publications than individuals in any other birth positions and are overrepresented among members of Congress and U.S. presidents. Hence, studies have consistently linked first-born children and academic achievement and revealed that the number of first-born National Merit Scholarship winners was found to equal the number of second- and third-born combined. Also, separate studies have found high academic achievement levels among first-born in both urban ghettoes in the United States and at British universities.

Firstborn Children often feel pressure to succeed or perform well, either by parents or through their own inner drives. They are often called on to take care of younger siblings or do chores in the family because they are responsible. Firstborns also feel pressure to be good examples for their siblings. Given the above, there could be more first born students among the work study students than other the second, middle and last born children.

\subsubsection{Second born and middle children}

According to Franz (2006), many second born children are also middle children and they usually feel inferior to older children because they do not possess their sibling's qualities. Although Franz (2006) argues that they could be very competitive with their firstborn siblings but others may choose to focus their energies in areas different from those in which their older siblings are already established for competition. Therefore, the competitive drive which some of them possess could prompt them to engage in innovation or doing things that would make them different from their older siblings in order to stand out in the family dynamic.

\subsubsection{Lastborn Children}

Last born children are the last children in the family. Most of them are over pampered and therefore are not usually very responsible. Due to their over pampered they not given any opportunity to do what will make them responsible. Parents can foster responsibility and self-reliance by giving even the youngest child some responsibility, such as setting the table or putting clean clothing in their dresser drawers. But more often than not, last born children are left without any responsibility. This could make them lazy in everything they do. They may not perform well academically in lower and higher education systems. Such students may not take part in work study scheme.

\subsection{Theoretical Explanation}

The Eysenck inventory theory has been regarded as one of the most widely used paradigms to assess personality traits of adult persons in work and educational settings. It is on this ground that the paradigm is considered most appropriate for a study of this nature.

The theory is rooted in the works of two renowned Psychologists (Mr. Hans Jürgen Eysenck and his wife Sybil B. G. Eysenck). The paradigm was propounded and standardized in the United Kingdom. It was designed mainly for measuring various types of Personality which has been classified into the following four types:

- Firstly, extroversion-introversion, and lie (Eysenck and Eysenck, 1975). Extraversion personality is characterized as sociable, jocularity, liveliness, optimism, quick-wittedness, responsive, active, risk taking, sensation seeking, expressive, lack of refection, dominant and impulsive (Yousef and El-Houfey, 2014) 
- Secondly, neuroticism-stability. Neuroticism personality is characterized by anxious, depressed, guilt feeling, low self-esteem, tense, moody, hypochondriac, lack of autonomy and obsessive (Yousef and El -Houfey, 2014). These authors proposed that individuals who score high on this dimension tend to be anxious, depressive, overly emotional, shy, and have low self-esteem, they often complain of physical symptoms such as headache and backache, but they also may be free symptoms (Tiwari, Singh and Sing 2009).

- Thirdly, psychoticism personality characterized by aggressive, assertive, egocentric, unsympathetic manipulative, achievement oriented, dogmatic, masculine and touch minded (Yousef and El -Houfey, 2014). High psychotic scores may indicate anxiety, hysteria, ego-centricism, nonconformance, aggression, impulsiveness, hostility and obsessive-compulsive disorders. Both normal and abnormal individuals may score high on the neuroticism scale.

- Fourthly, lie personality according to Eysenck and Eysenck (1975) is characterized by greater lies at their life minor or major. These scholars believe that lie personality people are characterized by telling false statements, ideas, actions to a person or group made by another person or group who knows it is not the whole truth, intentionally (Eysenck and Eysenck, 1975).

Considering the first classification in relation to work-study scheme, a student who is lively, responsive, active, risk taking, optimistic could easily engage in work-study scheme. The involvement may not necessarily be connected to inability to pay school fees, but for the fun of it or for wanting to be active and not dormant. Life may be very boring to students outside classroom, but when they indulge in work-study, they may be a little bit comfortable.

In respect of the second classification, students who are anxious and depressed, probably because of their inability to pay school fees may be compelled to participate in work study scheme. If they can resume studies due to financial challenge, they could be depressed and be anxious to participate so as to get money to complete their studies. However, this could be applied to students in the public sector higher education where the school fee is not too much. It may not be applicable to the private sector where the school fee is very high.

As regard the third category, students who are achievement oriented and dogmatic may want to assess the benefit inherent in participating in the work study programme. Probably because of allowance, work related experience etc.

The last attribute, lie, may not have any influence on the participation of students on work study scheme.

\section{Methods}

\subsection{Study Design}

This study employed ex-posit study design. This is because the study used data of students who participated in the work study programme in the past.

\subsection{Population of Study and Sample Size}

Students who have participated in work-study scheme in the institution under study in 2014/2015 academic session represent the population of this study. The total figure of students involved is 120 . Since the population was too small, there was no need of selecting a sample. The entire population became the sample of study.

\subsection{Sample Techniques}

Purposeful sampling technique was used to select respondents for this study. This method became inevitable considering the focus of the study which hinges mainly on work study students. Moreover, the population of the participating students was very small therefore; selecting a sample from the population would not be reasonable and representative enough.

\subsection{Instrument of data Collection}

The study engaged the use of questionnaire to collect the data used for this study. The instrument contained four sections. The first section contained the socio-demographic factors of respondents (age, sex and birth order of students) while the section B dealt with issues relating to personality Types ('A' and 'B') of students who participated in work study initiative. Section A contained four (4) questions but only one option was given to respondents (they were asked to indicate their sex, age, birth order and personality Type). Section B contained ten questions relating to students Personality Types. The following five (5) options with their ranks were given to students to choose from: 
- Strongly Agree 5

- Agree 4

- Undecided 3

- Disagree 2

- $\quad$ Strongly Disagree 1

\subsection{Validity and Reliability of Instrument.}

In Table 1 presented below, the internal consistence of the research instrument was measured using the Cronbach's statistic. Analysis of the result reveals Cronbach alpha coefficient greater than 6.42 with a total of 10 items measured by the present study. This further shows that questionnaire instrument measure of internal consistence is statistically satisfactory and will be able to reproduce similar outcome in repeated experiments. In ensuring the validity of the instrument, a face and content validity was carried out by a group of experts in this field.

Table 1: Reliability Statistics

\begin{tabular}{|c|c|}
\hline Cronbach's Alpha & N of Items \\
\hline .642 & 10 \\
\hline
\end{tabular}

Source: Computation by Researchers (2015)

\subsection{Analysis of data}

Simple percentage was used to analyze data relating to sex, age, birth order and categorization of students Personality Types while the chi-square, t-test and Pearson Correlation were used to test the hypotheses formulated.

\subsection{Research Questions}

The following research questions were raised for this study

1. What is the Personality Type composition of work study students?

2. What is the average age of work study students?

3. How do socio demographic factors (gender, age and birth order) influence work study students?

4. What influence does student Personality Type 'A' has on work study scheme?

5. Is there correlation between students Personality Type 'B' and work study scheme?

\subsection{Research Hypotheses}

The following hypotheses were formulated for testing and validation in this study

$\mathrm{H1}$ : Student socio-demographic characteristics influence work study programme

$\mathrm{H} 2$ : There is correlation between student Personality Type 'A' and work study initiative

H3: There is correlation between Personality Type ' $\mathrm{B}$ ' and participation of students in work study scheme.

Table 2: Gender Composition of Work-Study Students

\begin{tabular}{|c|c|c|c|}
\hline SN & Gender & Frequency $(\mathbf{N}=100)$ & $\%(100)$ \\
\hline 1 & Male & 31 & 31 \\
2 & Female & 69 & 69 \\
\hline
\end{tabular}

Source: Computation by Researchers (2015)

Dwelling on Table 2, female students who participated in work study scheme represent the absolute majority (69\%) in the sample while their male counterparts constitute the minority (31\%).

Considering the above result, it is most likely that female students have the capacity of combining the work study 
scheme with academic activities without any negative effects on their academic performance in as much as the study of Anugwom, Omonijo and Fadugba, (2010) on gender performance in higher education shows that female students usually perform better than their male counterparts. Putting this into consideration, female students may not find it difficult copping with academics and work activities on campus. Since the female folk is known for her daily chores than their male counter parts, it may become very easy for them to combine the two together.

Moreover, the result in Table 2a could be attributed to the desire of female students to get enough money to cater for their social and material needs. Women like money very well and they may like seizing the opportunity that work study offers to get more money for their needs (fashion, cosmetics like perfumes, jerry curl, perming).

Table 3a: Age Composition of Work-Study Students

\begin{tabular}{|c|c|c|c|}
\hline SN & Age Composition & Frequency $(\mathrm{N}=\mathbf{1 0 0})$ & $\%(\mathbf{1 0 0})$ \\
\hline 1 & $14-16$ & 08 & 8 \\
2 & $17-19$ & 70 & 70 \\
3 & $20-22$ & 22 & 22 \\
\hline
\end{tabular}

Source: Computation by Researchers (2015)

Table 3a presents age composition of work study students, with age group 17-19 having absolute majority of respondents $(70 \%)$ in the sample. This is followed by age group $20-22$ with $20 \%$ while age $14-16$ represents the least with $8 \%$.

One would have suggested that age group 20-22, being the oldest, would have represented the absolute majority of the sample, but the reverse is the case. Going by people's belief, older persons tend to be more informed than younger ones. Therefore, it is expected that age group 20-22 will know the importance of work study and be anxious to be involved in the scheme than younger ages. Also, it expected that this class of age would be more curious about job placement after graduation. Hence, they ought to have seen their involvement in the programme as an opportunity to be able to secure job after graduation than their counterparts, but the reverse is the case. Probably, students in age group 17-19 are better informed than the older age groups.

Table 3b: Average Age of Work Study Students

\begin{tabular}{|c|c|c|c|c|}
\hline SN & Age Group & Frequency $(\mathrm{N}=\mathbf{1 0 0})$ & Mid-Point $(\mathbf{N}=\mathbf{5 4})$ & $\mathrm{FM}^{2}(\mathbf{N}=\mathbf{1 8 4 2})$ \\
\hline 1 & $14-16$ & 08 & 15 & 120 \\
2 & $17-19$ & 70 & 18 & 1260 \\
3 & $20-22$ & 22 & 21 & 462 \\
\hline
\end{tabular}

Source: Computation by Researchers (2015)

Average $=\underline{1842}=18.42$

100

Therefore, the average age of work study student is 18 . Although the age is impressive, but it should have been higher had it been that older students participated more in the scheme. Table 3a presented above showed that students between the age of 17 and 19 represents the absolute majority (70\%) of the sample while older students between the age of 20 and 22 represents just $22 \%$ of respondents.

This age could be a good starting point for any student to commence work related activities in order to build his or her career.

Table 4: Birth Order Composition of Work-Study Students

\begin{tabular}{|c|c|c|c|}
\hline SN & Birth Order & Frequency (N=100) & $\%(100)$ \\
\hline 1 & $1^{\text {st }}$ & 32 & 32 \\
2 & $2^{\text {nd }}$ & 22 & 22 \\
3 & $3^{\text {rd }}$ & 17 & 17 \\
4 & $4^{\text {th }}$ & 9 & 9 \\
5 & Last & 20 & 20 \\
\hline
\end{tabular}

Source: Computation by Researchers (2015) 
As indicated in Table 3 above, first born children represent the majority of respondents with (28\%). This is followed by second born children with $22 \%$. Very closely to the $2^{\text {nd }}$ born order are last born children, which represent $20 \%$. The $3^{\text {rd }}$ and $4^{\text {th }}$ order respondents in the sample represent $9 \%$ and $17 \%$ respectively.

Dwelling on previous studies, $1^{\text {st }}$ born children tend to struggle more than other children in the family. This must have been responsible for the findings in this section.

Table 5: Personality Types Categorization of Work-Study Students

\begin{tabular}{|c|c|c|c|}
\hline SN & Personality Type & Frequency $(\mathrm{N}=100)$ & $\%(100)$ \\
\hline 1 & A & 64 & 64 \\
2 & B & 36 & 36 \\
\hline
\end{tabular}

Source: Computation by Researchers (2015)

Table 5 presents personality types categorization of work study students. Personality Type ' $A$ ' in the sample constitutes the majority with $64 \%$ while the Personality Type 'B' represents the minority with $36 \%$.

The result in Table 5 is not surprising, since the personality type ' $A$ ' attributes include hardworking, ambitious, highly competitive, achievement-oriented and striving as submitted by Glass (1977) the tendency of such students involving in work study scheme more than the personality type 'B' students could be greater. As a group of hard working students, combining work study scheme with academic activities may not be a problem to them. Also, as ambitious, highly competitive and achievement-oriented students, engaging could be perceived as a way of obtaining work related experience for work after graduation. Probably, they may see the scheme as a way of having a cutting edge above other non-work study students after graduation.

\subsection{Testing of Hypotheses}

The three hypotheses formulated to guide the process of this work are tested in this section.

Hypothesis I

$\mathrm{H}_{1}$ : Students socio demographic characteristics significantly influence work study programme

Table 6: Test Statistics

\begin{tabular}{|c|c|c|c|}
\hline & $\begin{array}{c}\text { Age of students can influence their } \\
\text { participation in work study scheme? }\end{array}$ & $\begin{array}{c}\text { Sex of students can influence their } \\
\text { participation in work study programme? }\end{array}$ & $\begin{array}{c}\text { Birth order can influence their } \\
\text { participation in work study initiative? }\end{array}$ \\
\hline $\begin{array}{c}\text { Chi-Square } \\
\text { df }\end{array}$ & $12.300^{a}$ & 29.800 a & $19.700^{a}$ \\
Asymp. Sig. & 4 & 4 & 4 \\
\hline
\end{tabular}

a. 0 cells (.0\%) have expected frequencies less than 5 . The minimum expected cell frequency is 20.0 .

In Table 6, the present study tests the hypothesis to verify whether the social demographic characteristics of students significantly influence their participation in work study programme. Given the chi- $X^{2}(12.30)$ result for the variable responses Age of students can influence their participation in work study scheme with degree of freedom, $\mathrm{df}=4$ and significance level of 5 percent; Sex of students can influence their participation in work study programme with chi- $X^{2}$ (29.80) and df $=4$ and significance level of 1 percent and Birth order can influence their participation in work study initiative with chi $X^{2}$ distribution $19.70, \mathrm{df}=4$ and asymptotic significance of 1 percent. This study therefore proceeds to accepting the hypothesis that socio demographic characteristics significantly influence participation of students in work study programme while objecting to the null hypothesis that socio demographic characteristics do not significantly influence participation of students in work study programme.

Socio-demographic characteristics of students include sex, age and birth order. The hypothesis tested above shows that these variables influence the participation of students in the work study initiative. Analysis of data in Table 6 shows that female students participated more in the scheme than their male counterparts. Since the scheme attracts some money, female students may want to involve in the scheme to get money to take care of their needs, which may not be adequately provided by their parents.

In respect of age, the average age of students who engaged in the scheme is 18 , which is very good for a serious 
child to start building his career.

With regard to birth order, first born students in the sample represent the majority with $32 \%$ participated more in the scheme than other births. Past studies show that 1st born children tend to struggle more than other children in the family. This must have been responsible for the result obtained in this study.

Hypothesis 2 scheme.

$\mathrm{H}_{1}$ : There is a significant difference in Personality Type composition of students who engaged in work study

Table 7(a): One-Sample Statistics

\begin{tabular}{|c|c|c|c|c|}
\hline & $\mathrm{N}$ & Mean & Std. Deviation & Std. Error Mean \\
\hline Personality type & 100 & 1.37 & .485 & .049 \\
\hline
\end{tabular}

Table 7(b): One-Sample Test

\begin{tabular}{|c|r|c|c|c|c|c|}
\hline & \multicolumn{3}{|c|}{ Test Value =0 } \\
\cline { 5 - 7 } & $\mathrm{t}$ & $\mathrm{df}$ & Sig. (2-tailed) & \multirow{2}{*}{ Mean Difference } & \multicolumn{2}{|c|}{$95 \%$ Confidence Interval of the Difference } \\
\cline { 6 - 7 } & & & & Lower & Upper \\
\hline Personality type & 28.234 & 99 & .000 & 1.370 & 1.27 & 1.47 \\
\hline
\end{tabular}

The result from Table 7 above test whether there exists a significance difference among the personality type composition of students who engaged in work study scheme. The result of the T-statistic (28.234) with the degree of freedom (DF=99) revealed a significance among the Personality Type "A" and "B" compositions at 1 percent level of significance. This therefore leads to the acceptance of the study hypothesis that there is a significant difference in Personality type composition of students who engaged in work study scheme and rejection of the null hypothesis which stating that there is no significant difference in Personality type composition of students who engaged in work study scheme. Also the standard deviation and error mean suggested no significant variations from the sample mean.

The result in Table 5 show a wide gap in the composition of Personality Type of students who participated in work study scheme, with Personality Type 'A' having absolute majority (64\%) while Personality Type 'B" represents simple majority (36\%).

Hypothesis 3

$\mathrm{H}_{1}$ : There is correlation between student Personality Type and work study initiative

Table 8: Correlations result

\begin{tabular}{|c|c|c|c|}
\hline & & $\begin{array}{l}\text { Personality } \\
\text { Type }\end{array}$ & $\begin{array}{l}\text { Do you think personality type can influence } \\
\text { participation of students in work study programme? }\end{array}$ \\
\hline \multirow{4}{*}{ Personality type } & $\begin{array}{l}\text { Pearson } \\
\text { Correlation }\end{array}$ & 1 & $.630^{\text {*t }}$ \\
\hline & Sig. (2-tailed) & & .000 \\
\hline & $\mathrm{N}$ & 100 & 100 \\
\hline & & $.630^{\text {th }}$ & 1 \\
\hline \multirow{2}{*}{$\begin{array}{l}\text { Do you think personality type can influence } \\
\text { participation of students in work study programme? }\end{array}$} & Sig. (2-tailed) & .000 & \\
\hline & $\mathrm{N}$ & 100 & 100 \\
\hline
\end{tabular}

**. Correlation is significant at the 0.01 level (2-tailed).

Evidence from the estimated correlation coefficient from Table 3 indicates a significant strong correlation $(0.630)$ between the response variables "Personality Type" and influence on student participation in work study programme. This evidence further shows a statistically significant direct relationship for the two response observations; Personality Type and its influence on student work study participation. Hence we accept the hypothesis that there is correlation between Personality Type and participation of students in work study initiative.

As indicated in Table 5, student Personality Type ' $A$ ' participated more in the work study scheme than Personality Type 'B'. Traits of Personality 'A' could encourage any student in this personality to engage in the scheme. 


\section{Summary of Major Findings}

This study found that socio-demographic characteristics significantly influence participation of students in work study programme. Moreover, it was found that a significant difference exist in Personality Type composition of students who engaged in work study scheme. Lastly, the study revealed that correlation exists between personality type and participation of students in work study initiative

\section{Recommendations and Conclusion}

Based on the major findings of this study, it is suggested that male students be encouraged to participate in work study initiative like their female counterparts. The study also suggests that $2^{\text {nd }}$ and $3^{\text {rd }}$ as well as the last orders of birth students and personality type 'B' student be properly encouraged to take part in work study scheme.

This study concludes that socio-demographic characteristics of students influence their participation in work study scheme.

\section{Acknowledgements}

This research was supported by the Covenant University Centre for Research, Innovation and Development, (CUCRID), Ota, Ogun-State, Africa.

Cite this article as- George, T. O., Anyaegbunam, M. C., Azuh, D., Chine, B. C and Omonijo, D. O. (2015). Mediterranean Journal of Social Sciences, volume (issue): pages.

\section{References}

Adewale, T. O. and Ajayi, N. A. (2010). Student Librarian Work Study Programmes in Academic Libraries: An Appraisal. Library Philosophy and Practice, March

Aliyu, J. S and J. A, Adeoye, (1991). Examination cheating among college students: A case studyof Advanced Teachers College, Ahmadu Bello University, Kano: The Nigerian Teacher, 1 (1):20-35

Bayer, A. E. (1967). Birth Order and Attainment of the Doctorate a Test of Economic Hypotheses. American Journal of Sociology, Chicago Journals, 72(5): 540-550

Boskey, E. (2014). Socioeconomic Status (SES). Available on http://std.about.com/od/glossary/g/sesgloss.htm

Cuccaro-Alamin S and Choy S. P. (1998). Postsecondary financing strategies: How undergraduates combine work, borrowing, and attendance. Washington, DC: Department of Education, National Center for Education Statistics; 1998.

Diego, S. (2015). Communicating Concepts. Available on http://iceskatingresources.org/A\&BTypePersonalities.html

Ehrenberg, R. G and Sherman, D. R. (1986). Employment while in college, academic achievement, and Post-college outcomes: A summary of results. Journal of Human Resources, 22(1): 1-23.

Eysenck, H. J., and Eysenck, S. B. G. (1975): Manual of the Eysenck Personality Questionnaire. London: Hodder and Stough

Franz, J. (2006). "Birth Order." Gale Encyclopedia of Children's Health: Infancy through Adolescence. Encyclopedia.com. 23 May. 2015 http://www.encyclopedia.com

Furr, S. R., and Elling, T. W. (2000). The influence of work on college student develop- ment. NASPA Journal, 37(2), 454-470.

Glass, D. C. (1977). Behaviour Patterns, stress and coronary disease.Hills dale. New Jersey: Erlbaum.

Henry, J. B. (1967). Part-time employment and academic performance of freshmen. Journal of College Student Personnel, 8(4), 257260.

Humphreys, M. S and Revelle, W. (1984). Personality, Motivation and Predicting Managerial Success. Journal of Vocational Behaviour, 26:189-205.

Igborgbor, F. O. and F. O., Igborgbor. (1999). Gender differences in the perception of students adjustment problems among secondary school students in Community; Implications for counseling. Journal of Educational Research and Development, 1(1): 154-165

Hill, T. (2001). 10 Things Your Boss Won't Tell You. Market watch. Available on http://www.marketwatch.com/story/10-things-your-bosswont-tell-you-1293757446378

Jalilian F., Karami, M. B., Ahmadpanah, M., Ataee, M., Ahmadi, J. T., Eslami, A. A and Mirzaei, A. M. (2015). Socio-demographic characteristics associated with cigarettes smoking, drug abuse and alcohol drinking among male medical university students in Iran, Journal of Res Health Sci. 2015 Winter;15(1):42-6.

Kanyengo, C. W. (2008). Student librarians? The University of Zambia Work Study Programme. The Association of Commonwealth Universities Libraries and Information Networks 5: 4-5.

Leman, K. (1998). The New Birth Order Book: Why You Are the Way You Are. Grand Rapids, Mich.: F. H. Revell.

Li-Chu, C. (2010). The study of the relationship among locus of control, emotional intelligence and prosocial behavior of elementary school students in Kaohsiung City. Retrieved from http://140.127.82.166/handle/987654321/4380 
Lombardo, J. (2015). Type A and Type B Personalities in Organizations: Definition \& Characteristics. Available on http://study.com/ academy/lesson/type-a-and-type-b-personalities-in-organizations-definition-characteristics.html

Lounsbury, J., Saudargas, R., and Gibson, L. (2004). An Investigation of Personality Traits in Relation to Intention to Withdraw From College. Journal of College Student Development, 45(5):517.

Marino, R., Armidale, N. S. W., Uribe, S., Thomson, A. M. (2015). The Socio-demographic characteristics of Australian, Chilean, and New Zealand dental students. Innovations and Socio-demographic Issues. Available on https://iadr.confex.com/iadr/2005Balt/ techprogram/abstract_63795.htm

Maurer, T., and Rafuse, N. (2001). "Learning and Litigating: Managing Employee Development and Avoiding Claims of Age Discrimination." Academy of Management Executive 15, no. 4.

Mark, H.S., Ernest, T. P., Ryan, D. P and Charles B. (2012). The Effects of Work on Leadership Development Among First-Year College Students. Journal of College Student Development, (53)2:300-324.

Mazarianof, (2012). A Socio-Demographic Characteristics. Study Mode. Available on http://www.studymode.com/essays/a-SocioDemographic-Characteristics-902355.html

National Center for Education Statistics. (1994). Undergraduates who work while enrolled in postsecondary education, 1989-1990 (U.S. Department of Education, Office of Educational Research and Improvement Publication No. NCES 94-311). Washington DC: U.S. Government Printing Office

National Center for Educational Statistics. (2008). Socioeconomic status. Available on http://nces.ed.gov/programs/coe/glossary/s.asp

Stern, D and Nakata, Y. (1991). Paid employment among U.S. college students: Trends, effects, and possible causes. Journal of Higher Education, 62(1): 25-43.

Ndagana, B. L and Ogunronbi (2006). Blazing the Trail in Poverty Alleviation among University Students in Nigeria: the Federal University of Technology Yola. Library Philosophy and Practice, 9(1): 1-8

Nekhwevha F. (1999). No matter how long the night, the day is sure to come: Culture and educational transformation in post-colonial Namibia and post-apartheid South Africa. International Review of Africa, 45(6):491-506.

Oludayo, O. A., Omonijo, D. O., Uche, O.O.C and Rotimi, A. O. (2014). Evaluation of Students Work-Study Programme: The Case of a Private (Faith-Based) Higher Education Institution, South-West, Nigeria. British Journal of Education, Society \& Behavioural Science; 4(6): 784-809.

Omonijo, D. O., Oludayo, A.O., Uche, O. O. C., Rotimi, O. A. (2014). Assessment of Job Assignments of Work-Study Students, Covenant University Ota, Nigeria. American Journal of Scientific Research, 104(4): 43-53.

Omonijo, D. O., Anyaegbunam, M. C., Oludayo, O. A., Nnedum, O. A. U. (2015). A Study of Socio-Economic Status of Work-Study Students, Covenant University, Ota. Africa. European Journal of Scientific Research, 130 (4): 376-388

Oswald, D. P.; Coutinho, M. J.; Best, A. M.; Nguyen, N. (2001). Impact of Socio-demographic Characteristics on the Identification Rates of Minority Students as Having Mental Retardation. Mental Retardation, 39(5): 351-67

Ozer, D. J. and Benet-Martinez, V. (2006). "Personality and the prediction of consequential outcomes". Annual Review of Psychology 57, $401-421$

Rhodes, S. R. (1983) "Age-Related Differences in Work Attitudes and Behavior: A Review and Conceptual Analysis." Psychological Bulletin 93(2): 328-367.

Robin, S. and Timothy, A. J. (1989). Essentials of Organisational Behaviour "Personality and Values" Chapter 2. Pearson Education Inc. Publishers, Prentice Hall

Rotimi, O. A., Omonijo, D. O and Uche, O. O. U. (2014). Influence of Personality Types and Socio-Demographic Characteristics of Students on Examination Malpractice in Ibadan. European Journal of Scientific Research, 124(4): 486-499

Rosenman, R. H and M. Friedman. (1974). Type A Behavior and your Heart. New York: Knopf

Scott, E. M. S. (2015). Type A Personality Traits: Characteristics and Effects of a Type A Personality What Does It Mean To Have A "Type A" Personality? Available on http://stress.about.com/od/understandingstress/a/type_a_person.htm

Tiwari, T., Singh A.L., and Sing, I.L. (2009): The short-form revised Eysenck personality questionnaire: A Hindi edition (EPQRS-H), Ind Psychiatry J. 18(1): 27-31

Toman, W. (1993). Family Constellation: Its Effects on Personality and Social Behavior. New York: Springer Publishing Company.

Wallace, M. (1999). Birth Order Blues: How Parents Can Help Their Children Meet the Challenges of Birth Order. New York: H. Holt.

Warr, P. B. (1994) "Age and Employment." In Handbook of Industrial and Organizational Psychology, vol. 4., 2d ed. Edited by H. C. Triandis and M. D. Dunnette. Palo Alto,

Yousef and El -Houfey, (2014). Compatibility of Personality Traits With The Profession For Faculty of Nursing Students at Assiut University. British Journal of Education, 2(3): 44-56. 